\title{
Root Morphology, Anatomy, and Mycorrhiza of Peristylus goodyeroides (D.Don) Lindl. (Orchidaceae) in Different Life Stages: Ecological Significance and Implication for Conservation
}

\author{
Gebby Agnessya Esa Oktavia ${ }^{1,2^{\star}}$, Siti Nurfadilah ${ }^{1}$, Nina Dwi Yulia ${ }^{1}$ \\ and Ema Hendriyani ${ }^{3}$ \\ ${ }^{1}$ Purwodadi Botanic Garden, Research Center for Plant Conservation - National Research and \\ Innovation Agency Jl. Raya Surabaya-Malang Km. 65 Purwodadi, Pasuruan, East Java, 67163, \\ Indonesia. \\ ${ }^{2}$ Department of Biology, Faculty of Science and Technology, Universitas Airlangga, Jl. Mulyorejo, \\ Surabaya, East Java 60115, Indonesia. \\ ${ }^{3}$ Eka Karya Bali Botanic Garden, Research Center for Plant Conservation - National Research and \\ Innovation Agency, Candikuning, Baturiti, Tabanan, Bali, 82191, Indonesia.
}

Authors' contributions

This work was carried out in collaboration among all authors. All authors read and approved the final manuscript.

Article Information

DOI: $10.9734 / A R R B / 2021 / v 36 i 1030443$ Editor(s):

(1) Dr. Bechan Sharma, University of Allahabad, India. Reviewers:

(1) Vishal Sharma, Government College For Girls, India (2) Andrey Popatanasov, Bulgarian Academy of Sciences, Bulgaria. Complete Peer review History: https://www.sdiarticle4.com/review-history/75281

Original Research Article

Received 06 September 2021

Accepted 12 November 2021

Published 18 November 2021

\begin{abstract}
Orchid roots have vital functions for water absorption, nutrient uptake, a place of symbiosis with mycorrhizal fungi, adaptation, and survival. The aim of the present study was to investigate root traits in terms of root morphological, anatomical, and mycorrhizal features of a terrestrial orchid, Peristylus goodyeroides in relation to an ecological significance of root traits in survival of seedlings, juveniles, and adults of the orchid. Results showed that some morphological characters (root length and depth), anatomical features (cortical cell size, xylem number and diameter), and mycorrhizal features (peloton size and number) were significantly different between seedlings, juveniles, and
\end{abstract}


adults. In relation to root functional traits, lowest root length, depth, xylem number and diameter, peloton size and number in seedlings can be associated with low capacity in water and nutrient acquisition that might explain low survival of seedlings relative to juveniles and adults. Present study has implication for orchid conservation suggesting high attention in low survival rate of seedlings related to specificity in some of their morphological, anatomical, and mycorrhizal features which can be associated with low capacity in water and nutrient acquisition. It is vital to ensure water availability for seedlings, particularly, during dry seasons to decrease high mortality of seedlings as such high mortality can have adverse impacts on long-term survival of the orchid population.

Keywords: Root; morphology; anatomy; mycorrhiza; orchid; life stage.

\section{INTRODUCTION}

Orchidaceae is one of the largest plant families containing over 25,000 species across the world, and it is also one of the most threatened plant families, with more than $50 \%$ of orchid species that have been assessed are categorised as threatened species under IUCN Red List [1,2,3]. The prominent figure of orchids in IUCN Red List is related to many factors threatening orchid's survival including (i) overcollection for commercialisation as orchids have a wide range of uses as ornamental plants, herbal medicines, food, etc. [4,5,6] (ii) deforestation, (iii) habitat degradation, and (iv) ecological disturbance [7]. Orchid conservation is crucial to save the plant family diversity, and understanding of the biology and ecology of the orchids is essential in the management of orchid conservation for the success conservation of the orchids $[8,9,10]$.

Roots are one of essential organs for plants including orchids that possess vital functions for water absorption, nutrient uptake, a place of symbiotic association with mycorrhizal fungi, adaptation, and survival $[11,12,13]$. Root traits in terms of morphological, anatomical, and mycorrhizal features are known to have ecological significance for survival of plants including orchids $[12,13,14,15,16,17,18,19,20]$. For example, morphological characters such as long, deep roots are essential for deep water acquisition to cope with drought for survival $[15,16,21]$. Furthermore, root anatomical features of plants, such as higher number and larger diameter of root xylem commonly associated with higher capacity in water acquisition are important during water-deficit in dry seasons for survival $[14,21,22]$. Moreover, mycorrhiza (formation of symbiotic association between plant and mycorrhizal fungi in roots) are essential to increase nutrient acquisition [23,24]. Fine structures of hyphae of mycorrhizal fungi have a capacity to take up nutrients (carbon, nitrogen and phosphorous) from soil and to transfer a portion of nutrients to the orchids $[25,26,27,28]$.

Mycorrhiza in orchid roots is characterised by a specific structure called pelotons (coiled hyphae of mycorrhizal fungi colonising cortical cells of orchid roots) that can be digested as nutrient source for the orchids [29,30]. Many chlorophyllous orchids that have photosynthetic capability for nutrient acquisition are known to form symbiotic association with mycorrhizal fungi to increase nutrient acquisition, called mixotrophic orchids combining dual nutrient acquisition from photosynthesis and symbiotic association with mycorrhizal fungi $[31,32,33,34]$.

Understanding the ecological significance of root traits in the survival of seedlings, juveniles, and adults within orchid population is important in the management of orchid conservation. Orchid seedlings, that are one of valuable components in the orchid population, are often rarely observed in long-term population studies [35] and appear to have low survival rate $[36,37]$. For example, low survival rate (only $0.5 \%$ ) of seedlings of a terrestrial orchid Cypripedium reginae that survived for four years with highest mortality occurring in 1- and 2- year old seedlings [38]. High mortality of seedlings was also found in a temperate Australian orchid (Caladenia arenicola) with less than $1 \%$ seeds producing seedlings that survived the dry season [39]. Low survival rate of seedlings was also found in Tolumnia variegata with $32.8 \%$ of the seedlings surviving for 1 year and $14.5 \%$ for 2 years $[36,40]$.

The low survival rate of seedlings of orchids are similar to that of most plants $[36,41,42]$. It seems common for most plants that mortality decline with life stage, as mortality was the highest in seedlings and decline in subsequent life stages (juveniles and adults) [36,42]. Very little is known about the ecological significance of root traits in 
relation to survival of orchids in different life stages. The aims of the present study were to investigate root traits in terms of morphological, anatomical, and mycorrhizal features in a terrestrial orchid, Peristylus goodyeroides (D.Don) Lindl., in different life stages (seedlings, juveniles, and adults) in relation to the ecological significance of root traits in survival of seedlings, juveniles, and adults of the orchid. Like other orchids and most plants, seedlings of $P$. goodyeroides are often rarely observed and appears to have low survival relative to juveniles and adults $[36,43]$.

The present study is a part of programs to support management of orchid conservation. Data of the morphological, anatomical, and mycorrhizal features of $P$. gooyeroides in relation to the survival of seedlings, juveniles, and adults of the orchid can increase our understanding about factors limiting the survival of orchids in the natural habitats and can be useful in the formulation of prescription for the effective management of orchid conservation.

\section{MATERIALS AND METHODS}

\subsection{Study Species}

The study site in the present study was located in the natural habitat of Peristylus goodyeroides, in Gajahrejo woodland, Purwodadi District, Pasuruan Regency, East Java, Indonesia. The population of $P$. goodyeroides in Gajahrejo woodland was composed by individuals at different life stages (seedlings, juveniles, and adults) with proportion of individuals increased with life stage. Adults composed the highest proportion, followed by juveniles and seedlings. Seedlings composed the lowest proportion in populations and appeared that seedlings had low survival rate relative to juveniles and adults [43].

\subsection{Investigation of root Morphological, Anatomical, and Mycorrhizal Features}

Roots of $P$. goodyeroides were collected in the natural habitat in Gajahrejo woodland, Purwodadi District, Pasuruan Regency, East Java, Indonesia in April 2021 during rainy season. Root traits in terms of root morphological, anatomical, and mycorrhizal features of $P$. goodyerides were investigated in different life stages of the orchid (seedlings, juveniles, and adults). Three individuals of each life stage were sampled for investigation of morphological, anatomical, and mycorrhizal features of each life stage. Root morphological characters were investigated through morphological characterisation by measuring root number, length, depth, diameter, tuber size (length and width) of each life stage of the orchid. To characterise anatomical characters of roots of each life stage of the orchid, three roots from three individuals (one root from one individual) of each life stage were sampled. The roots were divided into three segments (basal, middle, and apical). Transverse sections of each root segment were made by hand-sectioning [44] and the root anatomical and mycorrhizal features were observed under trinocular light microscope Olympus CX31. Anatomical characters of epidermis, cortex, endodermis, vascular bundles, and pith were observed under microscope. Epidermis thickness, cell size and layer length of outer and inner cortex, endodermis and stele diameter, xylem number and diameter were measured using a micrometer.

Mycorrhizal features of each life stage of $P$. goodyeroides were investigated in terms of the percentage of mycorrhizal fungi colonisation in cortical cells of roots of each life stage of $P$. goodyeroides and size of pelotons within cortical cells. Percentage of mycorrhizal fungi colonisation in root cortical cells was estimated as percentage of cortical cells that were colonised by mycorrhizal fungi (the presence of pelotons). Length and width of pelotons and the cortical cells were measured using a micrometer.

\subsection{Data Analysis}

Data of morphological characters (root number, length, depth, diameter, tuber size (length and width), anatomical characters (epidermis thickness, outer cortex and inner cortex cell size and layer length, endodermis and stele diameter, xylem number and diameter), and percentage of mycorrhizal fungi colonisation in cortical cells of roots of seedlings, juveniles, and adults of $P$. goodyeroides were analysed using ANOVA (Analysis of Variance) using Minitab 14.0. Correlation between peloton size and the cortical cell size (correlation between cortical cell length and peloton length; and correlation between cortical cell width and peloton width) was analysed using Analysis of Regression using Minitab 14.0.

\section{RESULTS AND DISCUSSION}

The present study showed root morphological, anatomical, and mycorrhizal features of $P$. goodyeroides in different life stages (seedlings, juveniles, and adults). 


\subsection{Morphological Characters of Roots of $P$. goodyeroides in Different Life Stages}

Results showed root morphological characters including root number, length, diameter, depth, tuber size (tuber length and width) of $P$. goodyeroides in different life stages. Seedlings, juveniles, and adults had significantly different root number (ANOVA, d.f. $=2, \mathrm{P}=0.001$ ), root length (ANOVA, d.f. $=2, P=0.027$ ), root depth (ANOVA, d.f. $=2, \mathrm{P}=0.011$ ), root diameter (ANOVA, d.f. $=2, \quad \mathrm{P}=0.028)$. All those morphological characters increased with life stage. Root number, length, depth, and diameter, tuber length and width were the lowest in seedlings and increasing in juveniles and adults (Table 1). Root number of seedlings, juveniles, and adults was $3.5 \pm 0.5,9.0 \pm 0.0$, and 12.5; respectively. Root length of seedlings, juveniles, and adults was $4.65 \pm 0.35 \mathrm{~cm}, 4.85 \pm 0.35 \mathrm{~cm}$, and $7.0 \pm 0.3 \mathrm{~cm}$; respectively. Root depth of seedlings, juveniles, and adults was $4.5 \pm 0.5$ $\mathrm{cm}, 7.7 \pm 0.7 \mathrm{~cm}$, and $9.9 \pm 0.1 \mathrm{~cm}$; respectively. Root diameter of seedlings, juveniles, and adults was $1.00 \pm 0.012 \mathrm{~cm}, 1.13 \pm 0.017 \mathrm{~cm}$, and 1.50 $\pm 0.116 \mathrm{~cm}$; respectively (Table 1 ).

Tubers of seedlings, juveniles, and adults of $P$. goodyeroides were significantly different in length (ANOVA, d.f. $=2, P=0.028$ ) and width (ANOVA, d.f. $=2, P=0.012$ ). Tuber length of seedlings, juveniles, and adults was $1.55 \pm 0.15 \mathrm{~cm}, 2.65 \pm$ $0.35 \mathrm{~cm}$, and $3.85 \pm 0.35 \mathrm{~cm}$; respectively. Tuber width of seedlings, juveniles, and adults was 0.5 $\pm 0.00 \mathrm{~cm}, 1.25 \pm 0.05 \mathrm{~cm}$, and $2.9 \pm 0.4 \mathrm{~cm}$; respectively (Table 1 ).

\subsection{Anatomical Characters of Roots of P.goodyeroides in Different Life Stages}

The anatomical organisation of roots of seedlings, juveniles, and adults of Peristylus goodyeroides was composed by components forming roots including epidermis, cortex (outer and inner cortex), endodermis, pericycle, vascular bundles (xylems and phloems), and pith (Table 2). There was no velamen. There were specific characters (raphide bundles and pelotons) in all life stages (seedlings, juveniles, and adults) (Table 2).

Comparison of root anatomical characters in different life stages of Peristylus goodyeroides showed that there were similarity and differences in anatomical characters between seedlings, juveniles, and adults. The similarities of anatomical characters between seedlings, juveniles, and adults were in epidermis layer number (1 layer), epidermis cell shape (polygonal), epidermis cell thickening $\cap$, cortex consisted of outer cortex and inner cortex, outer cortex layer number (2-3 layers), rounded to polygonal-shaped cells of inner cortex and outer cortex, the presence of raphides and pelotons, endodermis layer number (1 layer) with cell wall thickening $\mathrm{O}$, and pith was parenchymatous (Table 2).

The differences of the anatomical characters between seedlings, juveniles, and adults were in the number of inner cortex layer and vascular bundle archs. The number of inner cortex layer and vascular bundle archs increased with life stage (seedlings-juveniles-adults) (Table 1). Number of inner cortex layer was the lowest in seedlings (3-5 layers), and increased in juveniles (4-6 layers), and adults (5-7 layers). The number of vascular bundle archs also increased with life stage, with the lowest in seedlings (7-9 archs) increased in juveniles (9-11 archs) and adults (12-18 archs) (Table 2).

Moreover, seedlings, juveniles, and adults had significant differences in epidermis thickness (ANOVA, d.f. $=2, \quad P=0.000$ ), length of outer cortical cells (ANOVA, d.f. $=2, P=0.002$ ), width of outer cortical cells (ANOVA, d.f. $=2, P=0.004$ ), length of outer cortex layer (ANOVA, d.f. $=2$, $P=0.000$ ), width of inner cortical cells (ANOVA, d.f. $=2, P=0.019$ ), length of inner cortex layer (ANOVA, d.f. $=2, P=0.000$ ), length of total cortex layer (ANOVA, d.f. $=2, P=0.000$ ), endodermis diameter (ANOVA, d.f. $=2, P=0.001$ ), stele diameter (ANOVA, d.f. $=2, P=0.003$ ), $\quad$ xylem diameter (ANOVA, d.f. $=2, P=0.034$ ), and xylem number (ANOVA, d.f. $=2, P=0.006$ ) (Table 3). Length of inner cortical cells was marginally significant different between seedlings, juveniles, and adults (ANOVA, d.f. $=2, P=0.062$ ) (Table 3 ).

All those anatomical characters increased with life stage, with the lowest in seedlings, increased in juveniles, and the highest in adults (Table 3 ). Epidermis thickness of seedlings, juveniles, and adults was $21.62 \pm 0.41 \mu \mathrm{m}, 33.98 \pm 1.66 \mu \mathrm{m}$, and $45.94 \pm 1.65 \mu \mathrm{m}$; respectively. Outer cortex cell length of seedlings, juveniles, and adults was $38.68 \pm 2.23 \mu \mathrm{m}, 54.96 \pm 3.06 \mu \mathrm{m}, 57.73 \pm 0.80 \mu \mathrm{m}$; respectively. Outer cortex cell width of seedlings, juveniles, and adults was $31.60 \pm 2.50 \mu \mathrm{m}$, $44.62 \pm 1.58 \mu \mathrm{m}, 45.74 \pm 1.68 \mu \mathrm{m}$; respectively. Outer cortex layer length of seedlings, juveniles, and adults was $49.95 \pm 3.2 \mu \mathrm{m}, 62.52 \pm 2.44 \mu \mathrm{m}$, and $93.19 \pm 2.09 \mu \mathrm{m}$; respectively. 
Table 1. Morphological characters of seedlings, juveniles, and adults of Peristylus goodyeroides

\begin{tabular}{llll}
\hline Morphological characters & Seedlings & Juveniles & Adults \\
\hline Root number & $3.5 \pm 0.5(\mathrm{a})$ & $9.0 \pm 0.0(\mathrm{~b})$ & $12.5 \pm 0.5(\mathrm{c})$ \\
Root length $(\mathrm{cm})$ & $4.65 \pm 0.35(\mathrm{a})$ & $4.85 \pm 0.35(\mathrm{~b})$ & $7.0 \pm 0.3(\mathrm{c})$ \\
Root depth $(\mathrm{cm})$ & $4.5 \pm 0.5(\mathrm{a})$ & $7.7 \pm 0.7(\mathrm{~b})$ & $9.9 \pm 0.1(\mathrm{c})$ \\
Root diameter $(\mathrm{mm})$ & $1.00 \pm 0.012(\mathrm{a})$ & $1.13 \pm 0.017(\mathrm{~b})$ & $1.50 \pm 0.116(\mathrm{c})$ \\
Tuber length $(\mathrm{cm})$ & $1.55 \pm 0.15(\mathrm{a})$ & $2.65 \pm 0.35(\mathrm{~b})$ & $3.85 \pm 0.35(\mathrm{c})$ \\
Tuber width $(\mathrm{cm})$ & $0.5 \pm 0.00(\mathrm{a})$ & $1.25 \pm 0.05(\mathrm{~b})$ & $2.9 \pm 0.4(\mathrm{c})$ \\
\hline
\end{tabular}

Table 2. Comparison of root anatomical characters of seedlings, juveniles, and adults of Peristylus goodyeroides

\begin{tabular}{|c|c|c|c|}
\hline Anatomical characters & Seedlings & Juveniles & adults \\
\hline \multicolumn{4}{|l|}{ Epidermis } \\
\hline Epidermis layer number & 1 layer & 1 layer & 1 layer \\
\hline Epidermis cell shape & polygonal & polygonal & polygonal \\
\hline Epidermis cell thickening & & $\cap$ & \\
\hline \multicolumn{4}{|l|}{ Cortex } \\
\hline \multicolumn{4}{|l|}{ Outer cortex } \\
\hline Outer cortex layer number & 2-3 layers & 2-3 layers & 2-3 layers \\
\hline Outer cortex cell shape & rounded to polygonal & rounded to polygonal & rounded to polygonal \\
\hline \multicolumn{4}{|l|}{ Inner cortex } \\
\hline Inner cortex layer number & 3-5 layers & 4-6 layers & 5-7 layers \\
\hline Inner cortex cell shape & rounded to polygonal & rounded to polygonal & rounded to polygonal \\
\hline Total cortex layer number & 5-8 layers & $6-9$ layers & $7-10$ layers \\
\hline \multicolumn{4}{|l|}{ Specific characters } \\
\hline Raphides & yes & yes & yes \\
\hline Pelotons & yes & yes & yes \\
\hline \multicolumn{4}{|l|}{ Endodermis } \\
\hline Endodermis layer number & 1 layer & 1 layer & 1 layer \\
\hline Endodermis cell thickening & & $\mathrm{O}$ & $\mathrm{O}$ \\
\hline Pericycle & 1 layer & 1 layer & 1 layer \\
\hline \multicolumn{4}{|l|}{ Vascular bundle } \\
\hline Vascular bundle archs & $7-9$ & $9-11$ & $12-18$ \\
\hline \multicolumn{4}{|l|}{ Pith } \\
\hline Pith cell type & Parenchymatous & Parenchymatous & Parenchymatous \\
\hline Pith cell shape & Rounded to polygonal & Rounded to polygonal & Rounded to polygonal \\
\hline
\end{tabular}

Table 3. measurement of anatomical characters of seedlings, juveniles, and adults of Peristylus goodyeroides

\begin{tabular}{llll}
\hline Anatomical characters & Seedlings $(\boldsymbol{\mu m})$ & Juveniles $(\boldsymbol{\mu m})$ & Adults $(\boldsymbol{\mu m})$ \\
\hline $\begin{array}{l}\text { Transverse section } \\
\text { Transverse section length }\end{array}$ & $1039.67 \pm 48.28(\mathrm{a})$ & $1074.58 \pm 17.56(\mathrm{ab})$ & $1628.96 \pm 76.66(\mathrm{~b})$ \\
$\begin{array}{l}\text { Transverse section width } \\
\text { Epidermis }\end{array}$ & $1006.95 \pm 35.23(\mathrm{a})$ & $1048.79 \pm 18.40(\mathrm{ab})$ & $1540.43 \pm 85.99(\mathrm{~b})$ \\
Epidermis thickness & $21.62 \pm 0.41(\mathrm{a})$ & $33.98 \pm 1.66(\mathrm{~b})$ & $45.94 \pm 1.65(\mathrm{c})$ \\
$\quad \begin{array}{l}\text { Outer cortex } \\
\text { Length of outer cortical cell }\end{array}$ & $38.68 \pm 2.23(\mathrm{a})$ & $54.96 \pm 3.06(\mathrm{ab})$ & $57.73 \pm 0.80(\mathrm{~b})$ \\
$\quad$ Width of outer cortical cell & $31.60 \pm 2.50(\mathrm{a})$ & $44.62 \pm 1.58(\mathrm{ab})$ & $45.74 \pm 1.68(\mathrm{~b})$ \\
$\quad \begin{array}{l}\text { Length of outer cortex layer } \\
\text { Inner cortex }\end{array}$ & $49.95 \pm 3.22(\mathrm{a})$ & $62.52 \pm 2.44(\mathrm{~b})$ & $93.19 \pm 2.09(\mathrm{c})$ \\
Length of inner cortical cell & $99.36 \pm 7.35(\mathrm{a})$ & $100.02 \pm 1.72(\mathrm{a})$ & $117.89 \pm 3.90(\mathrm{~b})$ \\
$\quad \begin{array}{l}\text { Width of inner cortical cell } \\
\text { Length of inner cortex layer }\end{array}$ & $78.38 \pm 3.66(\mathrm{a})$ & $93.25 \pm 3.60(\mathrm{ab})$ & $103.55 \pm 5.62(\mathrm{~b})$ \\
Length of total cortex layer & $232.03 \pm 15.11(\mathrm{a})$ & $244.5 \pm 10.18(\mathrm{ab})$ & $358.34 \pm 16.28(\mathrm{~b})$ \\
Endodermis & $311.25 \pm 6.78(\mathrm{a})$ & $331.44 \pm 11.09(\mathrm{ab})$ & $476.61 \pm 12.10(\mathrm{~b})$ \\
Endodermis diameter & $275.69 \pm 22.56(\mathrm{a})$ & $291.52 \pm 19.94(\mathrm{ab})$ & $579.88 \pm 52.37(\mathrm{~b})$ \\
$\begin{array}{l}\text { Stele } \\
\text { Stele diameter }\end{array}$ & $197.96 \pm 1.27(\mathrm{a})$ & $249.60 \pm 26.80(\mathrm{ab})$ & $467.28 \pm 53.19(\mathrm{~b})$ \\
\hline
\end{tabular}




\begin{tabular}{llll}
\hline Anatomical characters & Seedlings $(\boldsymbol{\mu m})$ & Juveniles $(\boldsymbol{\mu m})$ & Adults $(\boldsymbol{\mu m})$ \\
\hline Vascular bundles & & & \\
Xylem diameter & $20.78 \pm 3.41(\mathrm{a})$ & $22.23 \pm 2.64(\mathrm{ab})$ & $32.43 \pm 0.85(\mathrm{~b})$ \\
Xylem number & $7.78 \pm 0.62(\mathrm{a})$ & $9.89 \pm 0.44(\mathrm{ab})$ & $15.33 \pm 1.64(\mathrm{~b})$ \\
\hline
\end{tabular}

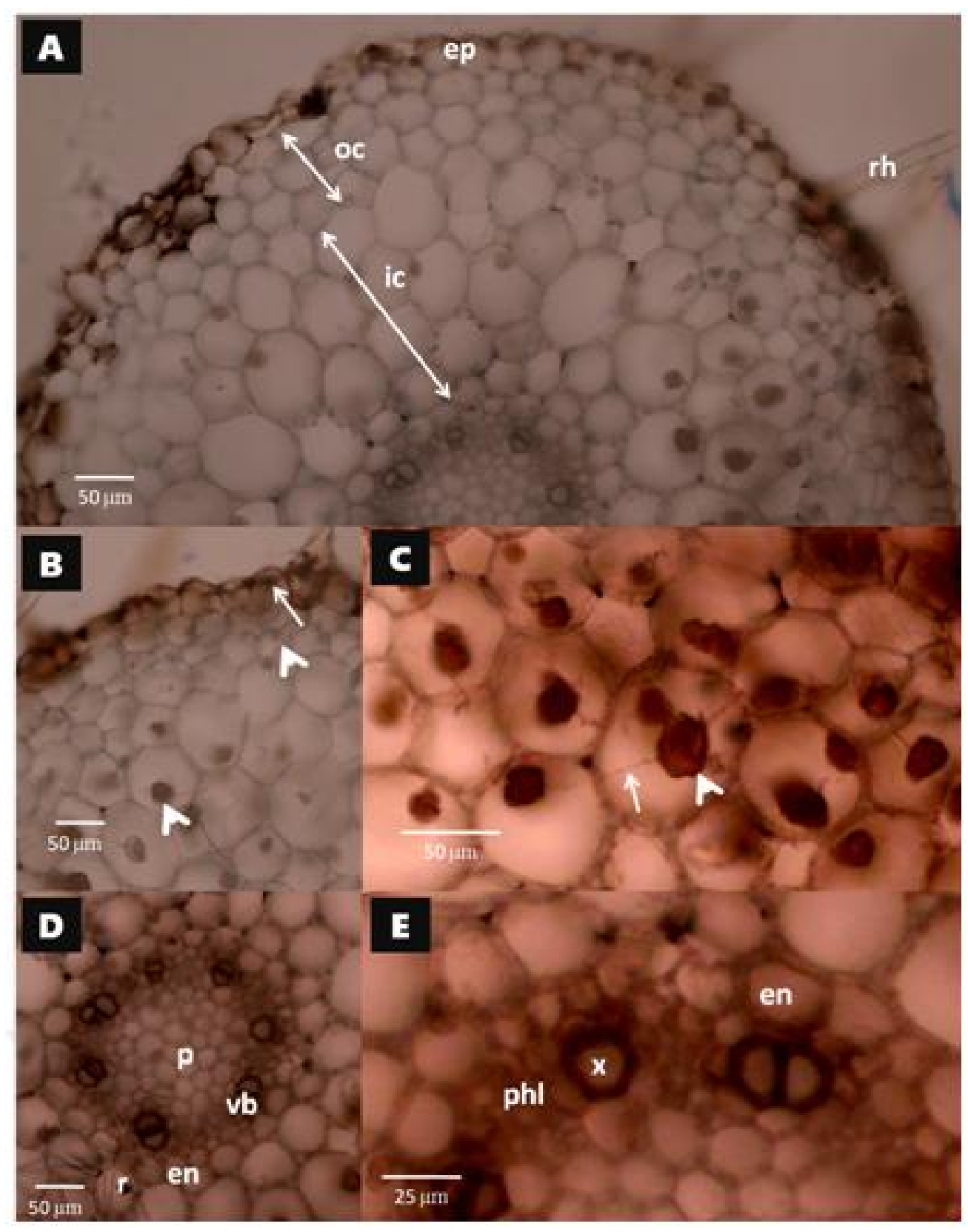

Fig. 1. Root anatomical characters of seedlings of $P$. goodyeroides. A. epidermis (ep) outer cortex (oc), inner cortex (ic), root hair (rh) B. fungal hyphae in epidermal cell (arrow), peloton in cortical cell (arrow head) C. Peloton in cortical cell (arrow head), fungal hyphae in cortical cell (arrow). D. endodermis (en), raphides ( $r$ ), pith ( $p)$, vascular bundles consisted of xylem and phloem (vb). E. Endodermis (en), xylem (x), phloem (phl) 


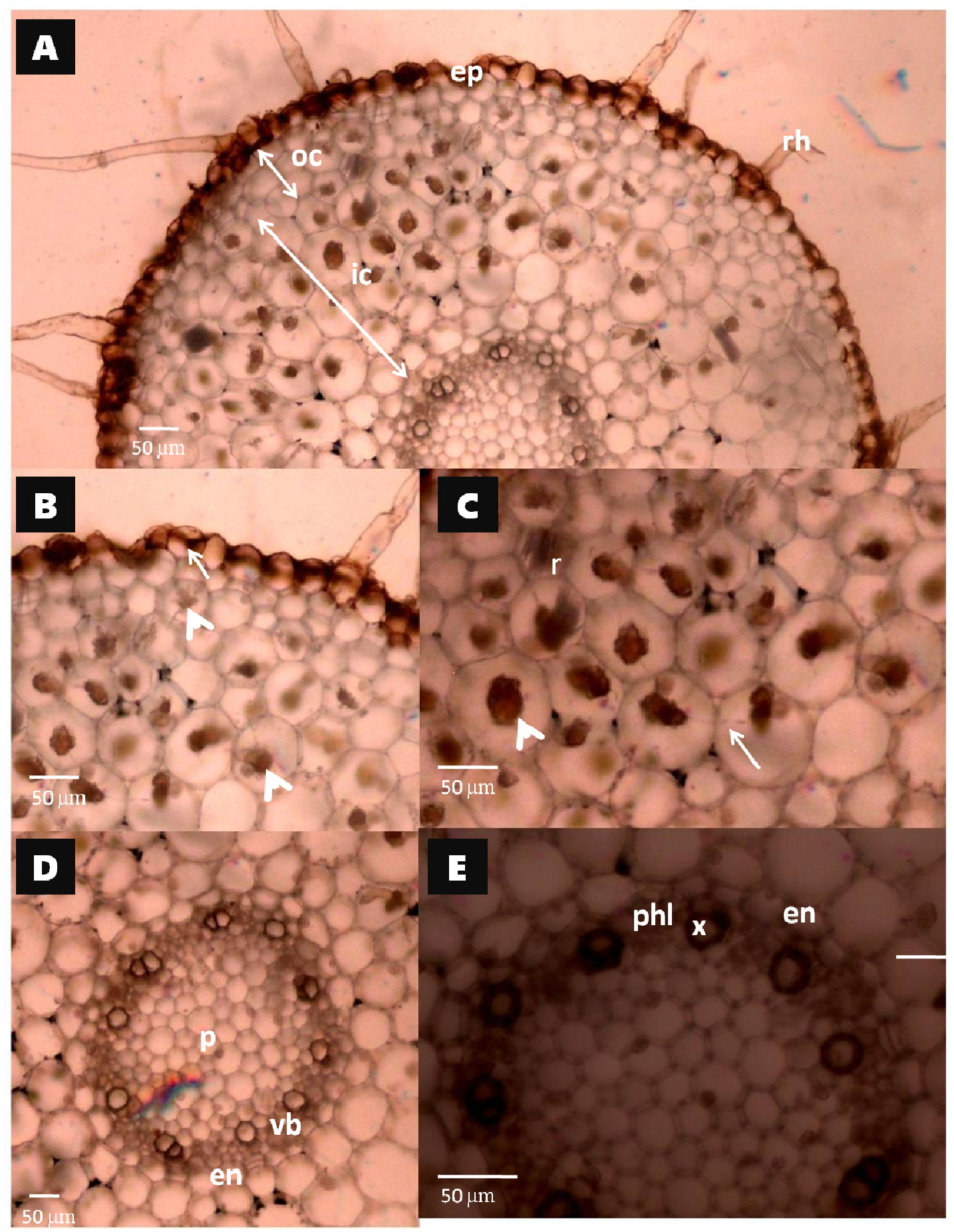

Fig. 2. Root anatomical characters of juveniles of $P$. Goodyeroides. A. epidermis (ep) outer cortex (oc), inner cortex (ic), root hair (rh) B. fungal hyphae in epidermal cell (arrow), peloton in cortical cell (arrow head) C. Peloton in cortical cell (arrow head), fungal hyphae in cortical cell (arrow) and raphides (r). D. endodermis (en), pith (p), vascular bundles consisted of xylem and phloem (vb). E. Endodermis (en), xylem (x), phloem (phl) 


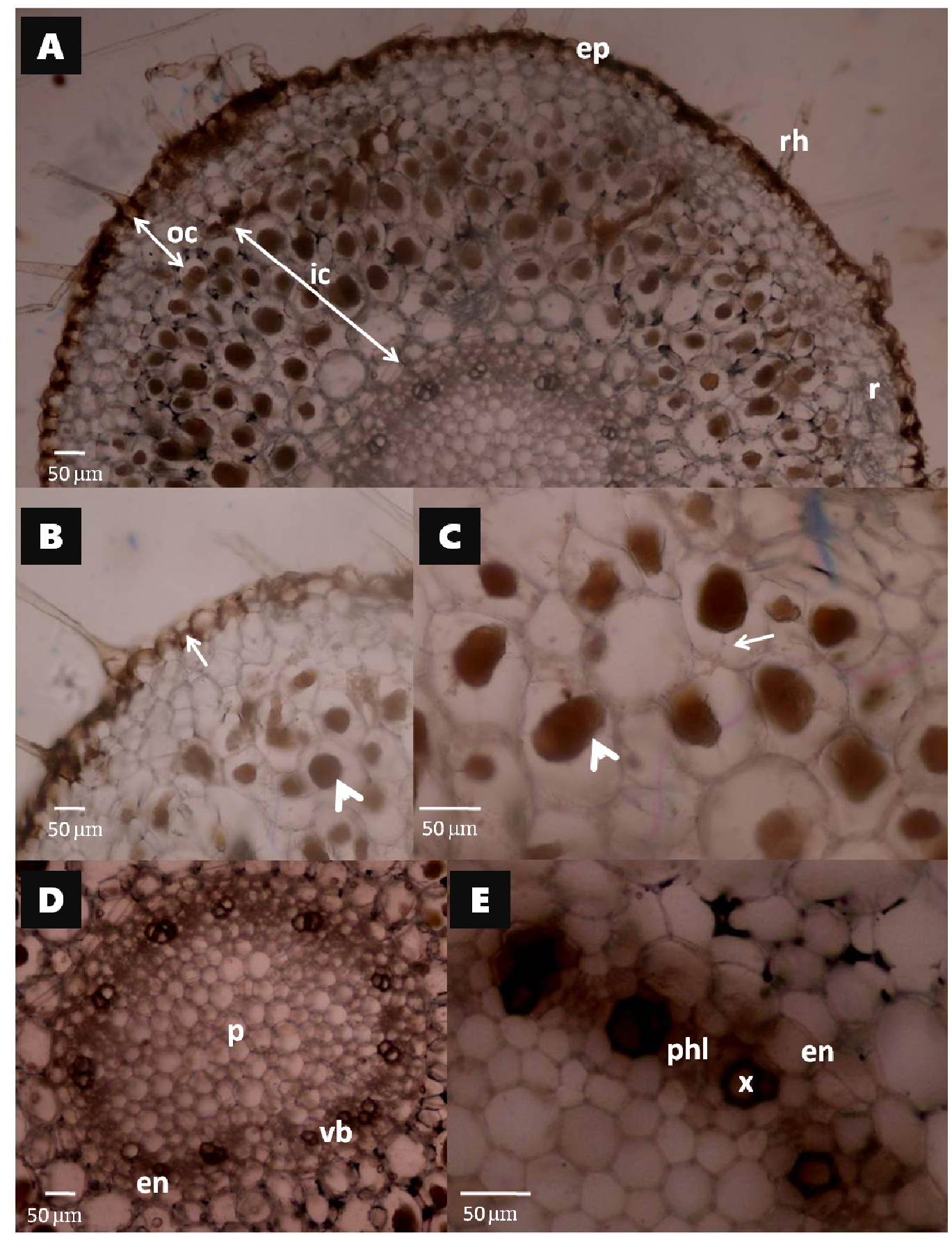

Fig. 3. Root anatomical characters of adults of $P$. Goodyeroides. epidermis (ep) outer cortex (oc), inner cortex (ic), root hair (rh) and raphides ( $r$ ) B. fungal hyphae in epidermal cell (arrow), peloton in cortical cell (arrow head) C. Peloton in cortical cell (arrow head), fungal hyphae in cortical cell (arrow). D. endodermis (en), pith (p), vascular bundles consisted of xylem and phloem (vb). E. Endodermis (en), xylem (x), phloem (phl)

Length of inner cortical cell of seedlings, juveniles, and adults was $99.36 \pm 7.35 \mu \mathrm{m}$, $100.02 \pm 1.72 \mu \mathrm{m}$, and $117.89 \pm 3.90 \mu \mathrm{m}$; respectively. Width of inner cortical cell of seedlings, juveniles, and adults was $78.38 \pm 3.66$ $\mu \mathrm{m}, 93.25 \pm 3.60 \mu \mathrm{m}$, and 103.55 $\pm 5.62 \mu \mathrm{m}$; 
respectively. Length of inner cortex layer of seedlings, juveniles, and adults was $232.03 \pm 15.11 \mu \mathrm{m}, \quad 244.5 \pm 10.18 \mu \mathrm{m}$, and $358.34 \pm 16.28 \mu \mathrm{m}$; respectively. Length of total cortex layer was $311.25 \pm 6.78 \mu \mathrm{m}, 331.44 \pm 11.09$ $\mu \mathrm{m}$, and $476.61 \pm 12.10 \mu \mathrm{m}$; respectively. Endodermis diameter of seedlings, juveniles, and adults was $275.69 \pm 22.56 \mu \mathrm{m}, 291.52 \pm 19.94 \mu \mathrm{m}$, and $579.88 \pm 52.37 \mu \mathrm{m} ;$ respectively. Stele diameter of seedlings, juveniles, and adults was $197.96 \pm 1.27 \mu \mathrm{m}, \quad 249.60 \pm 26.80 \mu \mathrm{m}$, and $467.28 \pm 53.19 \mu \mathrm{m}$; respectively. Xylem diameter of seedlings, juveniles, and adults was $20.78 \pm 3.41 \mu \mathrm{m}, 22.23 \pm 2.64 \mu \mathrm{m}$, and $32.43 \pm 0.85$ $\mu \mathrm{m}$; respectively. Xylem number of seedlings, juveniles, and adults was $7.78 \pm 0.62,9.89 \pm 0.44$, and $15.33 \pm 1.64$; respectively. (Table 3 )

\subsection{Mycorrhizal Features of $P$. goodyeroides in Different Life Stages}

Roots of $P$. goodyeroides in different life stages were mycorrhizal containing pelotons in the cortical cells with various extent of mycorrhizal fungi colonisation. Percentage of mycorrhizal fungi colonisation in seedlings, juveniles, and adults in basal, middle, and apical root sections was not significantly different (ANOVA, d.f. $=8, P=0.651$ ). Percentage of mycorrhizal fungi colonisation in cortical cells of seedlings (in basal, middle, and apical parts of the roots was $50.00 \pm 20.21,48.33 \pm 19.22$, and $56.67 \pm 20.28$, respectively), while the percentage of mycorrhizal fungi colonisation in cortical cells of juveniles (in basal, middle, and apical parts of the roots was $43.33 \pm 24.04,38.33 \pm 18.78$, and $65.00 \pm 22.55$; respectively). The percentage of mycorrhizal fungi colonisation in cortical cells of adults (in basal, middle, and apical parts of the roots was $75.00 \pm 2.89,70.00 \pm 17.56$, and $85.00 \pm 2.89$; respectively) (Table 4).

Analysis of regression between cortical cell size and peloton size showed positive correlation between cortical cell size and peloton size indicating that peloton size increased with the increase of cortical cell size. Peloton length was positively correlated with cortical cell length $(\mathrm{P}=0.003 ; \mathrm{R}=0.68)$. Peloton width was also positively correlated with cortical cell width $(\mathrm{P}=0.024 ; \mathrm{R}=0.55)$ (Fig. 4).

Table 4. Extent of mycorrhizal colonisation in different life stages of orchids

\begin{tabular}{lll}
\hline Orchid life stage & Root segments & Percentage of mycorrhizal fungi colonisation (\%) \\
\hline Seedling & Basal & $50.00 \pm 20.21(\mathrm{a})$ \\
& Middle & $48.33 \pm 19.22(\mathrm{a})$ \\
Juvenile & Apical & $56.67 \pm 20.28(\mathrm{a})$ \\
& Basal & $43.33 \pm 24.04(\mathrm{a})$ \\
& Middle & $38.33 \pm 18.78(\mathrm{a})$ \\
Adult & Apical & $65.00 \pm 22.55(\mathrm{a})$ \\
& Basal & $75.00 \pm 2.89(\mathrm{a})$ \\
& Middle & $70.00 \pm 17.56(\mathrm{a})$ \\
& Apical & $85.00 \pm 2.89(\mathrm{a})$ \\
\hline
\end{tabular}
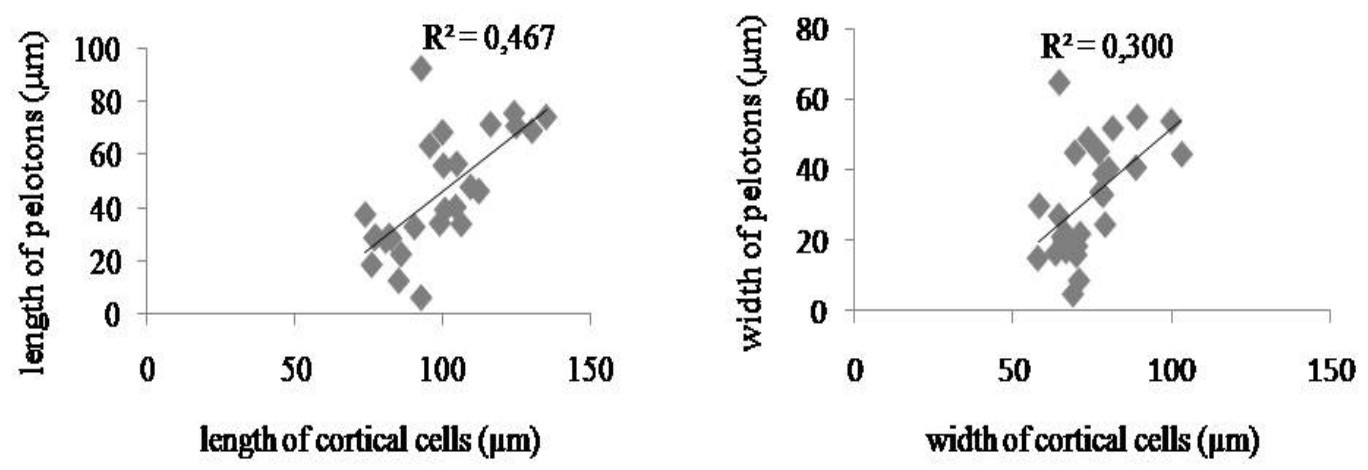

Fig. 4. Regression of peloton length and cortical cell length (left), regression of peloton width and cortical cell width (right) 


\subsection{Discussion}

Present study demonstrated root traits in terms of morphological, anatomical, and mycorrhizal features in different life stages (seedlings, juveniles, and adults) of $P$. goodyeroides in relation to the ecological significance of root traits in survival of seedlings, juveniles, and adults of the orchid. Morphological characters in root number, length, depth, and diameter of $P$. goodyeroides increased with life stage, with the lowest in seedlings, and increased in juveniles and adults. Some root morphological characters (root number, length, depth, and diameter) are known to associate with root capacity in water and nutrient acquisition [15,16,21]. Large number of roots may function to enhance water uptake efficiency [45], while long, deep roots are essential for deep water acquisition to escape drought for survival [15,16,21]. Furthermore, large root diameter is known to be a strategy to tolerate drought as thicker roots can support faster nutrient acquisition [46].

In the present study, adults had characters of the highest values in root number, length, depth, and diameter relative to juveniles and seedlings; and presumably had the highest capacity in water and nutrient acquisition compared to juveniles and seedlings in relation to their root functional traits. In contrast, seedlings had the lowest values in root number, length, depth, and diameter and probably had low capacity in water and nutrient acquisition that might explain the low survival rate of seedlings relative to juveniles and adults, particularly during dry season. Moreover, tuber essential as nutrient reserve to survive drought was also the smallest in seedlings that might be another factor explaining low survival of seedlings relative to juveniles and adults.

The anatomical differences between seedlings, juveniles, and adults can be seen in some anatomical characters, such as, number of inner cortex layer and vascular bundle archs that increased with life stage. Relative to juveniles and adults, seedlings had the smallest number of inner cortex layer and vascular bundle archs. Cortex and vascular bundles (xylem and phloem) are known as essential parts in roots that have vital function in nutrient and water acquisition. Cortex is known to associate with nutrient acquisition as cortex is the place of formation of pelotons (coiled hyphae of mycorrhizal fungi colonising cortical cells) that can be digested as nutrient source. This facilitates mycotrophy in orchids (obtaining nutrients from symbiotic association with mycorrhizal fungi) [30,31]. In relation to functional traits of cortex, the lowest number of cortex layer in seedlings as shown in the present study can be associated with low nutrient acquisition.

Furthermore, vascular bundles (xylems and phloems) are known to have functional traits in water and nutrient transport and absorption. In relation the functional traits of vascular bundles, the lowest number of vascular bundle archs in seedlings as shown in the pesent study can be associated with low capacity in water and nutrient acquisition. This might be another factor explaining the low rate of survival of seedlings, particularly during water deficit in dry season.

Other anatomical differences between seedlings, juveniles, and adults also can be seen from characters of epidermis thickness, cell size and layer length of outer cortex and inner cortex, endodermis and stele diameter, and xylem number and diameter. All those characters increased with life stage, with the highest values in adults and the lowest ones in seedlings. The prominent anatomical characters associating with survival are outer cortex and inner cortex in relation to the functional traits of cortex for nutrient acquisition, and xylem for water acquisition. Cell size and layer length of outer cortex and inner cortex, and xylem number and diameter that were lowest in seedlings might also explain low survival of seedlings relative to juveniles and adults.

In the present study, some mycorrhizal features, such as percentage of mycorrhizal fungi colonisation between seedlings, juveniles, and adults in basal, middle and apical of root segments were not significantly different. However, there were differences in the mycorrhizal features of the peloton size and number between seedlings, juveniles, and adults and the trend was to increase with life stage. Peloton size was positively correlated with cortical cell size. Another study also reported the positive correlation between peloton size and cortical cell size of other orchids [47]. The largest cortical cells in adults can accommodate the largest peloton size, while the smallest cortical cells in seedlings can accomodate the smallest peloton size. This might also explain low survival of seedlings relative to juveniles and adults. Furthermore, seedlings had the lowest number of cortex layers that can accommodate least pelotons in the cortical cells compared to juveniles and adults. This might be another factor 
explaining low survival rate of seedlings relative to juveniles and adults.

\section{CONCLUSION}

The present study showed that morphological, anatomical, and mycorrhizal features had ecological significance in survival of seedlings, juveniles, and adults of $P$. goodyeroides in relation to the capability in water and nutrient acquisition. In relation to root functional traits, lowest root length, depth and diameter, xylem number and diameter, peloton size and number in seedlings can be associated with low capability in water and nutrient acquisition that might explain low survival rate of seedlings relative to juveniles and adults.

\section{IMPLICATION FOR CONSERVATION}

The present study has implication in orchid conservation suggesting high attention in low survival of seedlings of $P$. goodyeroides, as well as other orchids, as low seedling survival is a common feature in orchids, similar to most plants. Low survival of seedlings appears to be related to the morphological, anatomical, and mycorrhizal features of seedlings that can be associated with low capacity in water and nutrient acquisition. It is vital to ensure water availability for seedlings, particularly, during dry seasons to decrease high mortality of seedlings. Watering of seedlings is known to be able to reduce seedling mortality [11] and can increase survival of seedlings that will have positive impacts on long-term survival of the orchid population.

\section{COMPETING INTERESTS}

Authors have declared that no competing interests exist.

\section{REFERENCES}

1. Chase MW, Cameron KM, Freudenstein JV, Pridgeon AM, Salazar G, Berg CVD, Schuiteman A. An updated classification of Orchidaceae. Botanical Journal of the Linnean Society. 2015;177: 151-174

2. Govaerts $R$, Bernet $P$, Kratochvil $K$, Gerlach G, Carr G, Alrich P, Pridgeon AM, Pfahl J, Campacci MA, Holland Baptista D, Tigges $H$, Shaw J, Cribb P, George A, Kreuz K, Wood JJ. World checklist of Orchidaceae. Kew: Facilitated by the Royal Botanic Gardens; 2017.
Available:http://apps.kew.org/wcsp/

3. Gale SW, Fischer GA, Cribb PJ, Fay MF. Orchid conservation: bridging the gap between science and practice. Botanical Journal of the Linnean Society. 2018;186:425-434.

4. Hinsley A, Boer HJD, Fay MF, Gale SW, Gardiner LM, Gunasekara RS, Kumar P, Masters S, Metusala D, Roberts DL, Veldman S, Wong S, Phelps J. A review of the trade in orchids and its implications for conservation. Botanical Journal of the Linnean Society. 2018;186:435-455.

5. Nurfadilah S. Utilization of orchids of Wallacea region and implication for conservation. IOP Conf. Series: Earth and Environmental 2020;473:012063:1-13.

6. Davenport TRB, Ndangalasi HJ. An escalating trade in orchid tubers across Tanzania's Southern Highlands: assessment, dynamics and conservation implications Oryx. 2003;37(1):55-61.

7. Rankou H. 2015. Paphiopedilum javanicum. The IUCN Red List of Threatened 2015: e.T43321232A43327894.

DOI:http://dx.doi.org/10.2305/IUCN.UK.20 15-2.RLTS.T43321232A43327894.en.

8. Swarts ND, Dixon KW. Terrestrial orchid conservation in the age of extinction. Annals of Botan. 2009;104:543 - 556.

9. Coates DJ, Dixon KW. Current perspectives in plant conservation biology. Australian Journal of Botany. 2007;55:187-193.

10. Phillips RD, Reiter N, Peakall R. Orchid conservation: from theory to practice. Annals of Botany. 2020;126:345-362.

11. Chen W, Koide RT, Adams TS, DeForest JL, Cheng L, Eissenstat DM. Root morphology and mycorrhizal symbioses together shape nutrient foraging strategies of temperate trees. PNAS. 2016;113(31):8741-8746.

12. Moreira ASFP, Filho JPdL, Isaias RMdS. Structural adaptations of two sympatric epiphytic orchids (Orchidaceae) to a cloudy forest environment in rocky outcrops of Southeast Brazil. Rev Biol Trop. 2013;61(3):1053-1065.

13. Nurfadilah S, Yulia ND, Ariyanti EE. Morphology, anatomy, and mycorrhizal fungi colonization in roots of epiphytic orchids of Sempu Island, East Java, Indonesia. Biodiversitas. 2016;17(2):592603. 
14. Prince SJ, Murphy M, Mutava RN, Durnell LA, Valliyodan B, Shannon JG, Nguyen HT. Root xylem plasticity to improve water use and yield in water-stressed soybean. Journal of Experimental Botany. 2017; 68(8):2027-2036.

15. Harrison $S$, LaForgia $M$. Seedling traits predict drought-induced mortality linked to diversity loss. PNAS. 2019;116(12):55765581

16. Garbowski M, Avera B, Bertram JH, Courkamp JS, Gray J, Hein KM, Lawrence $\mathrm{R}$, Mclntosh M, McClelland S, Post AK, Slette IJ, Winkler DE, Brown CS. Getting to the root of restoration: considering root traits for improved restoration outcomes under drought and competition. Restoration Ecology. 2020;28(6):13841395.

17. Zhang S, Yang Y, Li J, Qin J, Zhang W, Huang $W$, Hu $\mathrm{H}$. Physiological diversity of orchids. Plant Diversity. 2018;40:196-208.

18. Einzmann HJR, Schickenberg N, Zotz G. Variation in root morphology of epiphytic orchids along small-scale and large-scale moisture gradients. Acta Bot. Bras. 2020;34(1):66-73.

19. Tay JYL, Zotz G, Gorb SN, Einzmann HJR. Getting a Grip on the Adhesion Mechanism of Epiphytic Orchids Evidence From Histology and CryoScanning Electron Microscopy. Front. For. Glob. Change. 2021;4:764357

20. Holbein J, Shen D, Andersen TG. The endodermal passagecell-just another brick in the wall? New Phytologist. 2021;230:1321-1328.

21. Comas LH, Becker SR, Cruz VMV, Byrne $\mathrm{PF}$, Dierig DA. Roots traits contributing to plant productivity under drought. Frontiers in Plant Science. 2013;4:1-16.

22. Ouyang $W$, Yin $X$, Yang J, Struik PC. Comparisons with wheat reveal root anatomical and histochemical constraints of rice under water-deficit stress. Plant Soil. 2020;452:547-568.

23. Li T, Yang W, Wu S, Selosse M-A, Gao J. Progress and Prospects of Mycorrhizal Fungal Diversity in Orchids.Front. Plant Sci. 2021;12:646325.

24. Li T, Wu S, Yang W, Selosse M-A, Gao J. How mycorrhizal associations influence orchid distribution and population dynamics. Front. Plant Sci. 2021;12:647114.

25. Brundrett MC. Mycorrhizal associations and other means of nutrition of vascular plants: understanding the global diversity of host plants by resolving conflicting information and developing reliable means of diagnosis. Plant Soil. 2009;320:37-77.

26. Nurfadilah S; Swarts ND, Dixon KW, Lambers $\mathrm{H}$, Merritt DJ. Variation in nutrient-acquisition patterns by mycorrhizal fungi of rare and common orchids explains diversification in a global biodiversity hotspot. Ann Bot. 2013;111(6):1233-1241.

27. Cameron DD, Leake JR, Read DJ. Mutualistic mycorrhiza in orchids: evidence from plant-fungus carbon and nitrogen transfers in the green-leaved terrestrial orchid Goodyera repens. New Phytol. 2006;71:405-416.

28. Cameron DD, Johnson I, Leake JR, Read DJ. Mycorrhizal acquisition of inorganic phosphorus by the green-leaves terrestrial orchid Goodyera repens. Annals of Botany. 2007;99:831-834.

29. Sathiyadash K, Muthukumar T, Krthikeyan V, Rajendran K. Orchid mycorrhizal fungi : Structure, function and diversity. Springer Nature Singapore Pte Ltd.; 2020.

30. Rasmussen HN, Rasmussen FN. Orchid mycorrhiza: implications of a mycophagous life style. Oikos. 2009;118:334-345.

31. Ariza MC. Mycorrhizal associations, life history, and habitat characteristics of the endangered terrestrial orchid Spiranthes parksii corell and sympatric congener Spiranthes cernua: implications for conservation. Dissertation. Texas A\&M University; 2013.

32. Julou T, Burghardt B, Gebauer G, Berveiller D, Damesin C, Selosse MA. Mixotrophy in orchids: insights from a comparative studyof green individuals and nonphotosynthetic individuals of Cephalanthera damasonium. New Phytologist. 2005;166:639-653.

33. Selosse MA, Roy M. Green plants eating fungi: facts and questions about mixotrophy.Trends in Plant Sciences. 2009;4:64-70.

34. Yagame T, Orihara T, 'Selosse MA, Yamato $M$, Iwase $K$. Mixotrophy of Platanthera minor, an orchid associated with ectomycorrhiza-forming Ceratobasidiaceae fungi. The New Phytologist. 2012;193 (1):178-187.

35. Willems $\mathrm{JH}$. A founder population of Orchis simiain The Netherlands: a 30-year struggle for survival. InTrends and Fluctuations and Underlying Mech-anisms in Terrestrial Orchid Populations, ed. P. 
Kindlmann, J. H. Willems, \& D.F. Whigham, Leiden: Backhuys Publishers. 2002;23-32.

36. Shefferson RP, Jacquemyn $H$, Kull $T$, Hutchings MJ. The demography of terrestrial orchids: life history, population dynamics and conservation; 2020.

37. Whigham DF, McCormick MK, O'Neill JP. Specialized seedling strategies II: orchids, bromeliads, carnivorous plants, and parasites. Editors: Leck MA, Parker VT, Simpson RL. Cambridge University Press, New York. 2008;79-99.

38. Curtis JT. Germination and seedling development in five species of Cypripedium L. American Journal of Botany. 1943;30:199-206.

39. Batty $A L$, Dixon $K W$, Brundrett $M$, Sivasithamparam K. Constraints to symbiotic germination of terrestrial orchid seed in a mediterranean bushland.New Phytologist. 2001a;152:511-520.

40. Ackerman J, Sabat A, Zimmerman JK. Seedling establishment in an epiphytic orchid: an experimental study of seed limitation. Oecologia. 1996;106:192-198.

41. Hegazy AK. Age-specific survival, mortality, and reproduction, and prospects for conservation of Limonium delicatulum. Journal of Applied Ecology 29 (3): 549557.
42. Jones OR, Scheuerlein A, SalgueroGómez R, Camarda CG, Schaible R, Casper BB, Dahlgren JP, Ehrlén J, Garcia $M B$, Menges E, Quintana-Ascencio PF, Caswell H, Baudisch A, Vaupel JW. 2014. Diversity of ageing across the tree of life. Nature. 1992;505:169-173.

43. Nurfadilah S. Population study of Peristylus goodyeroides (Orchidaceae) in five habitats and implication for its conservation. Biodiversitas. 2017;18(3):1084-1091.

44. Matsuda Y, Amiya A, Ito S-i. Colonization patterns of mycorrhizal fungi associated with two rare orchids,Cephalanthera falcata and C. erecta. Ecol Res. 2009;24:1023-1031.

45. Hazman M, Brown KM. Progressive drought alters architectural and anatomical traits of rice roots. Rice. 2018;11:62.

46. Lozano YM, Aguilar-Trigueros CA, Flaig IC, Rillig MC. Root trait responses to drought are more heterogeneous than leaf trait responses. Functional Ecology. 2020;34:2224-2235

47. Sathiyadash $\mathrm{K}$, Muthukumar $\mathrm{T}$, Uma E, Pandey RR. Mycorrhizal association and morphology in orchids, Journal of Plant Interactions. 2012; 7:3:238-247.

(c) 2021 Oktavia et al.; This is an Open Access article distributed under the terms of the Creative Commons Attribution License (http://creativecommons.org/licenses/by/4.0), which permits unrestricted use, distribution, and reproduction in any medium, provided the original work is properly cited.

Peer-review history:

The peer review history for this paper can be accessed here: https://www.sdiarticle4.com/review-history/75281 